\title{
22q11.2 microdeletions in adults with familial tetralogy of Fallot
}

\author{
John S. Hokanson, $M D^{1}$, Mary Ella Pierpont, $M D, P h D^{2}$, Betsy Hirsch, $P h D^{3}$, and James H. Moller, $M D^{2}$
}

\begin{abstract}
Purpose: To determine the incidence of 22q11.2 microdeletions in the adult survivors of correction of tetralogy of Fallot who have familial congenital heart disease. Methods: Patients who had survived a correction of tetralogy of Fallot between 1954 and 1974 and had affected family members were identified during a study of these long-term survivors. Fluorescence in situ hybridization analysis was performed using both the N 25 (Oncor) and TUPLE1(VYSIS) probes, mapped to 22q11.2. Results: One of 18 (5.6\%) patients had a microdeletion within 22q11.2, including both N25 and TUPLE1. Conclusion: 22q11.2 microdeletions involving TUPLE1 and/or N25 are present in a minority of adults with familial tetralogy of Fallot. Genetics in Medicine, 2001:3(1):61-64.
\end{abstract}

Key Words: tetralogy of Fallot, 22q11.2 microdeletion, congenital heart disease, genetics

Recently, the understanding of the genetic basis of conotruncal cardiac malformations has undergone significant advances. Conotruncal cardiac malformation such as interruption of the aortic arch (type B), truncus arteriosus, and tetralogy of Fallot (TOF) may be part of a developmental field defect with varying clinical manifestations and are common in DiGeorge (DG), ${ }^{1}$ velocardiofacial $(\mathrm{VCF}),{ }^{2}$ and conotruncal anomaly face syndromes (CTAF). ${ }^{3}$ Most patients with DG, VCF, and CTAF syndromes have a chromosomal deletion within band 22q11.2 that can be demonstrated by high-resolution G-banding or fluorescence in situ hybridization (FISH) ${ }^{4-7}$

The clinical expression of this microdeletion can be highly variable between individual patients, ${ }^{8,9}$ within families, ${ }^{10-12}$ and even between monozygotic twins. ${ }^{13-15}$ The phenotype associated with 22q11.2 microdeletions may be subtle and difficult to detect, particularly in the neonatal period. 22q11.2 microdeletions have been reported in nonsyndromic patients with isolated conotruncal cardiac malformations, ${ }^{16,17}$ and occasionally, the noncardiac 22q11.2 phenotype of patients with TOF is not detected until after the molecular diagnosis has been made. ${ }^{18}$

Of the conotruncal malformations, TOF is by far the most common, occurring in roughly one in 3000 live births. ${ }^{19}$ Truncus arteriosus and interruption of the aortic arch (type B) occur in 1:18,000 and 1:30,000 births, respectively. ${ }^{19}$ The detection of a microdeletion within 22q11.2 in a patient with TOF provides very useful information to the clinician. The newborn with a 22q11.2 microdeletion is potentially immunodeficient

\footnotetext{
From the ${ }^{1}$ Children's Hospital of Illinois and University of Illinois College of Medicine at Peoria, Peoria, Illlinois; ${ }^{2}$ Department of Pediatrics, University of Minnesota; and ${ }^{3}$ Department of Laboratory Medicine and Pathology, University of Minnesota.

John S. Hokanson, MD, Pediatric Cardiology, University of Wisconsin, H4/442 Clinical Science Center, 600 Highland Avenue, Madison, WI 53792.

Received: August 23, 2000.

Accepted: October 25, 2000.
}

and at risk for hypocalcemia. Recent surveys suggest that renal and skeletal abnormalities may also be more common than previously suspected. ${ }^{8}$ These children may also benefit from further evaluation and early intervention for speech and other developmental delays. The detection of the 22q11.2 microdeletion in an adult patient with TOF also provides useful information for genetic counseling.

\section{METHODS}

In a previous study, ${ }^{20}$ we evaluated the very long-term follow-up after correction of TOF at the University of Minnesota. In that project, we evaluated the 288 patients who were discharged after a corrective operation between 1954 and 1974. None of these individuals had tetralogy of Fallot with pulmonary atresia (TOF/PA). All individuals in this group are at least of child-bearing age, and several have had grandchildren.. No patients in this population were known to have DG, VCF, or CTAF syndromes.

All available pedigrees were reviewed and classified by the cardiac malformations in the extended family. If multiple family members were affected, the pedigree was classified by the most severe malformation in the nearest relative. As these records included evaluations of children from more than 40 years ago, a diagnosis more specific than "blue baby" (dying in infancy) was unavailable in 4 families. As most patients had left the Minneapolis/St. Paul metropolitan area in the decades after their operation, a systematic evaluation of their noncardiac phenotype was not possible.

Those long-term survivors of TOF correction with an affected first-degree relative, or with extended family members with TOF were invited to participate. Three long-term postoperative survivors were excluded from participation. One individual adopted in infancy and unaware of their adoption and family history was excluded. Two patients in whom their immediate family members' cardiac malformation was limited to aortic valve disease were also excluded, as aortic stenosis re- 
lated to a bicuspid aortic valve was not believed to be a finding specific of a 22q11.2 microdeletion.

Four postoperative patients with affected family members were excluded as they and their affected family members had died during the follow-up period. Affected adult offspring of deceased patients were invited if they had been patients at the University of Minnesota. One affected child of a deceased index patient was excluded, as he was $<18$ years of age. After these exclusion criteria were applied, 24 long-term survivors and two affected offspring were eligible for study.

This project was evaluated and approved by the Human Subjects Committee of the University of Minnesota's Institutional Review Board. Informed consent was obtained from all participants.

Peripheral blood lymphocytes from study participants were stimulated with phytohemagglutinin and cultured under routine conditions for cytogenetic analysis. Metaphase cells were harvested and prepared onto glass slides. FISH was performed with DNA probes TUPLE1 (VYSIS) and N25 (ONCOR), mapped to 22q11.2 and a control probe (ARSA), which mapped to $22 \mathrm{q} 13.3$. FISH was performed according to manufacturer's instructions.

For each study participant, 20 metaphase cells were examined by FISH. Ten cells were examined with TUPLE1, and 10 with N25. Only cells in which the control probe localized to both copies of chromosome 22 were used for scoring. A patient was considered deleted if, in all cells examined, one chromosome \#22 hybridized to all probes being evaluated and the other \#22 showed hybridization to ARSA but not to TUPLE1 or N25.

\section{RESULTS}

These 288 patients have had 242 children, of which 10 $(4.2 \%)$ have a cardiac malformation (TOF, 4 ; ventricular septal defect [VSD], 4; double outlet right ventricle, 1; atrial septal defect, 1). This incidence is consistent with previously reported recurrence rates. ${ }^{3-5}$ None of these patients' 33 grandchildren have a cardiac malformation.

Of the 288 postoperative survivors, 30 (10.4\%) had at least one first-degree relative with a congenital cardiac malformation (TOF, 11; VSD, 10; aortic stenosis, 2; atrioventricular canal $[\mathrm{AVC}], 2$; partial anomalous pulmonary venous return [PAPVR], 1; "blue baby," 4). Three other patients have a second- or third-degree relative with TOF.

Seventeen long-term survivors of TOF repair and the affected offspring of one deceased patient participated in this study. The cardiac malformation in the nearest relative and results of FISH analysis are shown in Table 1 . One of the 18 patients $(5.6 \%)$ had a deletion encompassing both TUPLE1 and N25 in all 20 cells examined. She has had one miscarriage and her only living child has TOF and trisomy 21 . The family declined to have this child tested for the $22 \mathrm{q} 11.2$ microdeletion.
TABLE 1

22q11 microdeletions in adults with familial tetralogy of Fallot

\begin{tabular}{|c|c|c|c|}
\hline Gender & Age & $\begin{array}{l}\text { Affected family members and type } \\
\text { of cardiac malformation }\end{array}$ & FISH results \\
\hline $\mathrm{F}$ & 40 & Sibling-TOF & Not deleted \\
\hline $\mathrm{F}$ & 34 & Sibling-TOF & Not deleted \\
\hline $\mathrm{F}$ & 32 & Sibling-TOF & Not deleted \\
\hline $\mathrm{F}$ & 32 & Sibling-TOF & Not deleted \\
\hline $\mathrm{F}$ & 36 & Sibling-TOF & Not deleted \\
\hline M & 59 & $\begin{array}{l}\text { Sibling-PAVC, }{ }^{a} \text { sibling-"blue baby," } \\
\text { niece-TOF/PA }\end{array}$ & Not deleted \\
\hline $\mathrm{F}$ & 39 & Sibling-AVC, sibling-"blue baby" & Not deleted \\
\hline M & 27 & Sibling-VSD & Not deleted \\
\hline F & 38 & Sibling-PAPVR, cousin-"blue baby" & Not deleted \\
\hline M & 48 & Sibling-"blue baby" & Not deleted \\
\hline $\mathrm{F}$ & 29 & Child-TOF, trisomy 21 & Deleted \\
\hline $\mathrm{F}$ & 43 & Child-TOF & Not deleted \\
\hline $\mathrm{F}$ & 46 & Child-TOF & Not deleted \\
\hline M & 37 & Child-TOF & Not deleted \\
\hline M & 28 & Parent-VSD, grandparent-VSD & Not deleted \\
\hline $\mathrm{F}$ & 43 & Niece-TOF, cousin-“blue baby” & Not deleted \\
\hline $\mathrm{F}$ & 45 & Cousin-TOF & Not deleted \\
\hline $\mathrm{F}^{b}$ & 30 & $\begin{array}{l}\text { Mother-deceased index patient/ } \\
\text { daughter-VSD }\end{array}$ & Not deleted \\
\hline
\end{tabular}

${ }^{a}$ PAVC, partial AV canal.

${ }^{b}$ Daughter of deceased index patient.

No deletions of TUPLE1 or N25 were detected in the remaining 17 patients who participated in this project. Results with TUPLE1 were the same as those with N25 in all patients.

\section{DISCUSSION}

In the literature regarding 22q11.2 microdeletions in TOF, the cardiac and extracardiac phenotypes have been used inconsistently to differentiate between groups more or less likely to carry this microdeletion. If all types of TOF are included, the incidence of microdeletions varies between $8.0 \%$ and $26.5 \% .{ }^{17,18,21-24}$ When patients with pulmonary atresia or absent pulmonary valve syndrome are excluded, the incidence varies between $4.3 \%$ and $21.2 \% .{ }^{17,18,22-24}$ In these reports, most patients were evaluated in infancy or early childhood.

Our patient population differs from these reports not only in their age at evaluation, but also in that they have the potential selection bias of having affected family members, presumably increasing the likelihood of a heritable cause for their congenital heart disease. Although a higher incidence of $22 \mathrm{q} 11.2$ microdeletions might have been suspected in this population of patients with TOF and familial congenital heart disease, this was not the case. This lower incidence of the 22q11.2 microdeletion in our population may reflect a true difference in the 
frequency of 22q11.2 microdeletions between adult and pediatric populations with TOF. If TOF is present in the context of a 22q11.2 microdeletion, both the cardiac and extracardiac manifestations of this deletion could have a negative effect on long-term survival.

In an article by Rhoden et al., ${ }^{25} \mathrm{~T}$-cell deficiencies were much more common in nonsurvivors than survivors of surgery for conotruncal cardiac defects. Sullivan et al. have reported that the immune deficiencies seen in patients with the 22q11.2 microdeletion do not correlate with the clinical phenotype and are not limited to those individuals with DG. ${ }^{26}$ If patients with a deletion in the 22q11.2 locus correlate to the subset of patients with T-cell abnormalities, it is possible that these patients would be underrepresented in a population of adult survivors of corrective operations for TOF.

The lower incidence of 22q11.2 microdeletions in our population may reflect an increased severity of cardiac lesions in tetralogy of Fallot in the context of a 22q11.2 microdeletion. With abnormal development of pulmonary arteries, significant segments of the pulmonary vascular bed may be supplied by major aortopulmonary collaterals, complicating the operative correction and increasing the incidence of peripheral pulmonic stenosis. The frequency of major aortopulmonary collateral arteries is higher in TOF/PA in the context of the 22q11.2 microdeletion ${ }^{24,27}$ and may also be more common in TOF without pulmonary atresia in the context of the 22q11.2 microdeletion. ${ }^{28}$ Other complicating cardiac malformations may also be present in this setting. ${ }^{29}$

In a study of familial conotruncal defects, Wilson et al. ${ }^{30}$ found a microdeletion at $22 \mathrm{q} 11.2$ in the five families studied, all of which had at least one member with TOF or TOF/PA. However, in a study of familial nonsyndromic conotruncal defects by Debrus et al., ${ }^{31}$ TOF was present in 13 of 16 families studied. None of these individuals in Debrus' report were found to have a microdeletion at the 22q11.2 locus by FISH analysis. Digilio et al..$^{32}$ found that $10.3 \%$ of patients with TOF who did not carry the 22q11.2 microdeletion had first-degree relatives with congenital heart disease, a figure almost identical to our findings. From our report and those of Debrus et al. and of Digilio et al., it is clear that there are many instances of familial tetralogy of Fallot in which the 22q11.2 microdeletions encompassing N25 and or TUPLE1 is not the mechanism of inheritance. One possibility that cannot be excluded in the present study is the existence of loci within $22 \mathrm{q} 11.2$ other than D22S75 and TUPLE1 that can influence the development of the relevant cardiac malformations. Recent case reports by Rauch et al. ${ }^{33}$ and Saittaa et al. ${ }^{34}$ suggest that the existence of such loci distal to TUPLE1 (and outside the commonly deleted region in DG and VCF syndromes) cannot be excluded.

The incidence of cardiac malformations in the offspring of our group of long-term survivors after a corrective operation for TOF is not significantly different than in previous reports. ${ }^{35}$ Our data do not suggest that operative correction has allowed a significantly greater portion of patients with TOF and a 22q11.2 microdeletions involving TUPLE1 or N25 to reach child-bearing age.

\section{CONCLUSION}

The incidence a 22q11.2 microdeletion appears to be lower in long-term operative survivors than in infants and children with tetralogy of Fallot. The incidence of a 22q11.2 microdeletion may be lower in adult patients after correction of TOF due to attrition related to both the extracardiac and cardiac effects of this microdeletion. Although the incidence of a deletion as detected by current FISH technology is lower in long-term operative survivors, the presence of this deletion has significant implications for both clinical management and genetic counseling. Screening for a 22q11.2 microdeletion should be considered in adult patients after operative correction of TOF, particularly in the setting of familial congenital cardiac malformations. The absence of this microdeletion does not exclude the possibility that the offspring of adult patients with TOF will have a congenital cardiac malformation.

\section{Acknowledgments}

This study was performed at the Minneapolis Campus of the University of Minnesota. Support for this project was provided by the Dwan Family Endowment for Education in Pediatric Cardiology, the Anderson Center for Hereditary Cardiac Disease, and the General Clinical Research Center at the University of Minnesota (protocol 531).

\section{References}

1. Van Mierop LHS, Kutsche LM. Cardiovascular anomalies in DiGeorge syndrome and importance of neural crest as a possible pathogenic factor. Am J Cardiol 1986; 58:133-137.

2. Young D, Sphrintzen RJ, Goldberg RB. Cardiac malformations in the velocardiofacial syndrome. Am J Cardiol 1980;46:643-648.

3. Momma K, Kondo C, Matsuoka R, Takao A. Cardiac anomalies associated with a chromosome 22q11 deletion in patients with conotruncal anomaly face syndrome. Am J Cardiol 1996;78:591-594.

4. Driscoll DA, Budarf ML, Emanuel BS. A genetic etiology for DiGeorge syndrome: consistent deletions and microdeletions of 22q11. Am J Hum Genet 1992;50:924933.

5. Driscoll DA, Salvin J, Sellinger B, Budarf ML, McDonald-McGinn DM, Zackai EH, Emanuel BS. Prevalence of 22q11 microdeletions in DiGeorge, and Velocardiofacial syndromes: implications for genetic counseling and prenatal diagnosis. J Med Genet 1993;30:813-817.

6. Wilson DI, Burn J, Scrambler P, Goodship J. DiGeorge syndrome: part of CATCH 22. J Med Genet 1993;30:852-856.

7. Matsuoka R, Takao A, Kimura M, Imamura S, Kondo C, Joh-o K, Ikeda K, Nishibatake M, Ando M, Momma K. Confirmation that the conotruncal anomaly face syndrome is associated with a deletion within 22q11.2. Am J Med Genet 1995:53: 285-289.

8. Ryan AK, Goodship JA, Wilson DI, Levy PN, Seidel H, Schuffenhauer S, Oechsler H, Belohradsky B, Prieur M, Aurias A, Raymond FL, Clayton-Smith J, Hatchwell E, McKeown C, Beemer FA, Dallapiccola B, Novelli G, Hurst JA, Ignatius J, Greeen AJ, Winter RM, Brueton L, Brondum-Neilsen K, Stewart F, Van Essen T, Patton M, Paterson J, Scrambler PJ. Spectrum of clinical features associated with interstitial chromosome 22q11 deletions: a European collaborative study. J Med Genet 1997; 34:798-804.

9. Lipson A, Emmanuel B, Colley P, Fagan K, Driscoll D. "CATCH 22" sans cardiac anomaly, thymic hypoplasia, cleft palate, and hypocalcemia: $\mathrm{CATCH} 22$. A common result of 22q11 deficiency? J Med Genet 1994;31:741.

10. Kasprzak L, Der Kaloustian VM, Elliott AM, Shevell M, Lejtenyi C, Eydoux P. Deletion of 22q11 in two brothers with different phenotype. Am J Med Genet 1998;75: $288-291$.

11. Holder SE, Winter RM, Kamath S, Scrambler PJ. Velocardiofacial syndrome in a mother and daughter: variability of the clinical phenotype. J Med Genet 1993;39:825-827.

12. Desilva D, Duffty P, Booth P, Auchterlonie I, Morrison N, Dean JCS. Family studies in chromosome 22q11 deletion: further demonstration of phenotypic heterogeneity. Clin Dysmorphol 1995;4:294-303. 
13. Goodship J, Cross I, Scrambler P, Burn J. Monozygotic twins with chromosome 22q11 deletion and discordant phenotype. J Med Genet 1995;32:746-748.

14. Fryer A. Monozygotic twins with $22 \mathrm{q} 11$ deletion and discordant phenotypes. JMed Genet 1996;33:173.

15. Yamagishi H, Ishii C, Maeda J, Kojima Y, Matsuoka R, Kimura M, Takao A, Matsuo N. Phenotypic discordance in monozygotic twins with 22q11.2 deletion. Am J Med Genet 1998;78:319-321.

16. Goldmuntz E, Driscoll D, Budarf ML, Zackai EH, McDonald-McGinn DM, Biegel JA, Emanuel BS. Microdeletions of chromosomal region 22q11 in patients with congenital cardiac malformations. J Med Genet 1993;30:807-812.

17. Trainer AH, Morrison N, Dunlop A, Wilson N, Tolmie J. Chromosome 22q11 microdeletions in tetralogy of Fallot. Arch Dis Child 1996;74:62-63.

18. Amati F, Mari A, Diglio MC, Mingarelli R, Marino B, Giannotti A, Novelli G, Dallapiccola B. 22q11 deletions in isolated and syndromic patients with tetralogy of Fallot. Hum Genet 1995;95:479-482.

19. Ferencz C, Loffredo CA, Rubin JD, Magee CA. Perspectives in pediatric cardiology. Vol. 4. Epidemiology of congenital heart disease: the Baltimore-Washington infant study 1981-1989. Mount Kisco, NY: Futura Publications, 1993;

20. Hokanson JS, Moller JH. Very long term follow-up (22-42 Years) after correction of Tetralogy of Fallot: transient complete heart block is associated with increased risk of late sudden death [Abstract]. J Am Coll Cardiol 1998;31;355A.

21. Goldmuntz E, Clark BJ, Mitchell LE, Jawad AJ, Cuneo BF, Reed L, McDonald-McGinn D, Chein P, Feuer J, Zackai EH, Emanuel BS, Driscoll DA. Frequency of 22q11 deletions in patients with conotruncal defects. J Am Coll Cardiol 1998;32:492-498.

22. Webber S, Hatchwell I, Barber JCK, Daubeney PEF, Crolla JA, Salmon AP, Keeton BR, Temple IK, Dennis NR. Importance of microdeletions of $22 \mathrm{q} 11$ as a cause of selected malformations of the ventricular outflow tracts and aortic arch: a three-year prospective study. J Pediatr 1996;129:26-32.

23. Johnson MC, Hing A, Wood MK, Watson MS. Chromosomal abnormalities in congenital heart disease. J Med Genet 1997;70:292-298.

24. Chessa M, Butera G, Bonhoeffer P, Iserin L, Kachaner J, Lyonnet S, Munnich A, Sidi $\mathrm{D}$, Bonnet D. Relation of genotype $22 \mathrm{q} 11$ deletion to phenotype of pulmonary vessels in tetralogy of Fallot and pulmonary atresia-ventricular septal defect. Heart 1998;79:186-190.

25. Rhoden DK, Leatherbury L, Helman S, Gaffney M, Strong WB, Guill MF. Abnor malities in lymphocyte populations in infants with neural crest cardiovascular defects. Pediatr Cardiol 1996;17:143-149.

26. Sullivan KE, Jawad AF, Randall P, Driscoll D, Emmanuel BS, McDonald-Ginn DM, Zackai EH. Lack of correlation between impaired T cell production, immunodeficiency, and other phenotypic features in chromosome 22q11.2 deletion syndromes (DiGeorge syndrome/velocardiofacial syndrome). Clin Immunol Immunopathol 1998;86:141-146

27. Momma K, Kondo C, Matsuoka R. Tetralogy of Fallot with pulmonary atresia associated with chromosome 22q11 deletion. J Am Coll Cardiol 1996;27:198-202.

28. Momma K, Kondo C, Ando M, Matsuoka R, Takao A. Tetralogy of Fallot associated with chromosome 22q11 deletion. Am J Cardiol 1995;76:618-621.

29. Marino B, Diglio MC, Grazioli S, Formigari R, Mingarelli R, Giannotti A, Dallapiccola B. Associated cardiac anomalies in isolated and syndromic patients with tetralogy of Fallot. Am J Cardiol 1996;77:505-508.

30. Wilson DI, Goodship JA, Burn J, Cross IE, Scrambler PJ. Deletions within chromosome 22q11 in familial congenital heart disease. Lancet 1992;340:573-574.

31. Debrus S, Berger G, de Meeus A, Sauer U, Guillaumont A, Voisin M, Bozio A Demczuk S, Aurias A, Bouvagnet P. Familial non-syndromic conotruncal defects are not associated with a 22q11 microdeletion. Hum Genet 1996;97:138-144.

32. Digilio MC, Marino B, Giannotti A, Toscano A, Dallapiccola B. Recurrence risk for isolated tetralogy of Fallot after screening for 22q11 microdeletion. J Med Genet 1997;34:188-190.

33. Rauch NH, Pfeiffer RA, Leipold G, Singer H, Tiggs M, Hofbeck M. A novel 22q11.2 microdeletion in DiGeorge syndrome. Am J Hum Genet 1999;64:659-667.

34. Saitta SC, McGrath JM, Mensch H, Shaikh TH, Zackai EH, Emanuel BS. A 22q11.2 deletion that excludes UFD1L and CDC45L in a patient with conotruncal and craniofacial defects. Am J Hum Genet 1999;64:562-566.

35. Nora JJ, Nora AH. Recurrence risks in children having one parent with a congenital heart disease. Circulation 1976;53:701-702. 